\title{
Removal of Azo Dyes Reactive Black from Water by Zero-Valent Iron: The Efficiency and Mechanism
}

\author{
Y.Y. Xue*, L.P. Liang*十, Q. Wu*, Y.T. Zhang*, L.B. Cheng* and X. Meng**† \\ *School of Civil Engineering, College of Life Science, College of Textile and Garment, Shaoxing University, Shaoxing, \\ 312000, P.R.China \\ **Key Laboratory of Clean Dyeing and Finishing Technology of Zhejiang Province, Shaoxing University, Shaoxing, \\ 312000, P.R.China \\ $\dagger$ Corresponding author: Liping Liang; liangliping0702@163.com
}

\section{Nat. Env. \& Poll. Tech. Website: www.neptjournal.com \\ Received: 09-03-2020 \\ Revised: 21-04-2020 \\ Accepted: 15-06-2020 \\ Key Words: \\ Azo dyes \\ Reactive black \\ Zero-valent iron \\ Removal kinetics}

\begin{abstract}
The removal kinetics and mechanism of active black removal by zero-valent iron were investigated. The experimental results showed that the rate of reactive black removal by zero-valent iron increased with the decreasing of $\mathrm{pH}$ and initial dye concentration, and increased with the increasing of temperature and $\mathrm{ZVI}$ dosage. $\mathrm{SO}_{4}{ }^{2-}$ promoted the removal rate of reactive black. $\mathrm{Ca}^{2+}$ had an inhibitory effect on the removal of reactive black in the early stage by zero-valent iron and promoted it in the later stage, while $\mathrm{Mg}^{2+}, \mathrm{CO}_{3}{ }^{2-}, \mathrm{ClO}_{4}^{-}, \mathrm{NO}_{3}^{-}, \mathrm{PO}_{4}{ }^{3-}$ and $\mathrm{HCO}_{3}^{-}$all inhibited the removal rate of reactive black by zerovalent iron. The activation energy was $26.38 \mathrm{KJ} \mathrm{mol}^{-1}$ by using the Arrhenius formula, indicating that this reaction was easy to occur. The degradation process was further analysed by UV-Vis, SEM and XRD, and the main reaction product was $\mathrm{Fe}_{2} \mathrm{O}_{3}$.
\end{abstract}

\section{INTRODUCTION}

Reactive black is a large-volume, typical and widely used double-activated azo dye (Wu et al. 2017). It is used for dyeing and printing cotton, hemp, silk and nylon. Reactive black is soluble in water and is blue and black (Qiu 2010). In addition to the azo bond, the reactive black also contains a group such as a benzene ring, a naphthalene ring or a sulfonic acid group (Zhang et al. 2015). Although reactive black itself is less toxic, studies have shown that its hydrolysate toxicity is significantly increased (Zhang et al. 2004). Besides, the dyed waste liquid will have a large amount of reactive black entering the water environment endangering human health. At present, dye wastewater treatment methods mainly include adsorption method, electrochemical method, advanced oxidation method, biological method, etc. However, they all have certain limitations, such as easy to cause secondary pollution, high cost, low efficiency and harsh operating conditions (Feng et al. 2014).

As a kind of water treatment agent with wide source, simple operation and low price, zero-valent iron (ZVI) has been widely used in groundwater remediation, industrial wastewater treatment and drinking water treatment with groundwater contaminated by heavy metals (Bao et al. 2017).
The standard oxidation electrode of ZVI has a low potential $(\mathrm{E}=-0.44 \mathrm{~V})$ and can reduce most of the contaminants. The mechanism of ZVI to remove pollutants is mainly the use of iron reduction, micro-electrolysis, and coagulation adsorption (Fu 2010). At the end of the 20th century, scholars had studied the removal of chlorinated organic wastewater from water by zero-valent iron. With the gradual serious pollution of groundwater arsenic at home and abroad, zero-valent iron was widely used to repair the pollution of groundwater arsenic (Ludwig et al. 2009). A large number of scholars have studied the use of zero-valent iron to remove refractory nitrate wastewater (Rodríguez-Maroto et al. 2008), and zero-valent iron is also used to remove azo dyes. Epolito et al. (2008) studied the effects of different operating conditions on decolorizing reactive blue 4 of zero-valent iron. Khan et al. (2016) using ultrasonic waves to promote the surface of zero-valent iron to treat printing and dyeing wastewater. Guan et al. (2015) summarized the possible reactions of zero-valent iron in water as follows:

$$
\begin{aligned}
& \mathrm{Fe}^{0}+2 \mathrm{H}^{+} \rightarrow \mathrm{Fe}^{2+}+\mathrm{H} \\
& 2 \mathrm{Fe}^{0}+\mathrm{O}_{2}+2 \mathrm{H}_{2} \mathrm{O} \rightarrow 2 \mathrm{Fe}^{2+}+4 \mathrm{OH} \\
& \mathrm{Fe}^{2+}+2 \mathrm{H}_{2} \mathrm{O} \rightarrow \mathrm{Fe}(\mathrm{OH})_{2} \downarrow+2 \mathrm{H}^{+} \\
& 6 \mathrm{Fe}^{2+}+\mathrm{O}_{2}+6 \mathrm{H}_{2} \mathrm{O} \rightarrow 2 \mathrm{Fe}_{3} \mathrm{O}_{4} \downarrow+12 \mathrm{H}^{+} \\
& 4 \mathrm{Fe}^{2+}+\mathrm{O}_{2}+10 \mathrm{H}_{2} \mathrm{O} \rightarrow 4 \mathrm{Fe}(\mathrm{OH})_{3} \downarrow+8 \mathrm{H}^{+}
\end{aligned}
$$




$$
\begin{aligned}
& 4 \mathrm{Fe}^{2+}+\mathrm{O}_{2}+6 \mathrm{H}_{2} \mathrm{O} \rightarrow 4 \mathrm{FeOOH} \downarrow+8 \mathrm{H}^{+} \\
& \mathrm{Fe}^{0}+\mathrm{O}_{2}+2 \mathrm{H}^{+} \rightarrow \mathrm{Fe}^{2+}+\mathrm{H}_{2} \mathrm{O}_{2} \\
& \mathrm{Fe}^{2+}+\mathrm{H}_{2} \mathrm{O}_{2} \rightarrow \mathrm{Fe}^{3+}+\cdot \mathrm{OH}+\mathrm{OH}^{-}
\end{aligned}
$$

However, there were still few studies investigated the mechanism of the removal of reactive black by zero-valent iron. Hence, this study selected reactive black as the target pollutant and looked for the best operating conditions for zero-valent iron removal of reactive black, the influence of common coexisting ions in the water on the removal process were studied, and the degradation mechanism was also studied.

\section{MATERIALS AND METHODS}

\section{Materials}

The ZVI used in the experiment was purchased from Shanghai Haotian Co., Ltd. Reactive black, nitric acid and other reagents were analytical grade and purchased from Sinopharm Co., Ltd. The maximum absorption wavelength of reactive black is $587 \mathrm{~nm}$ and the dye structure is given in Table 1 .

\section{Batch Experiments and Chemical Analysis}

This experiment used a mechanical stirrer to stir, the rotation speed was $400 \mathrm{r} / \mathrm{min}$, so that the ZVI was evenly dispersed in the water. The temperature was kept constant by using a cryostat during the experiment. $0.01 \mathrm{M}$ acetic acid-sodium acetate buffer was used in the experiment to keep the $\mathrm{pH}$ value constant during the reaction. In the experiment, a certain amount of ZVI was weighed and placed in a jar containing 500 $\mathrm{mL}$ of dye solution. After a certain period of reaction, used a plastic syringe to take $5 \mathrm{~mL}$ of the water sample, passed the $0.45 \mu \mathrm{m}$ filter and directly measured the spectrophotometric value at $587 \mathrm{~nm}$ using a spectrophotometer. The solid sample after the reaction was subjected to suction filtration through a vacuum suction filter, freeze-dried, and stored for use, and subjected to solid-state characterization by a scanning electron microscope (SEM, Zeiss EVO LS-185) and an X-ray diffractometer (XRD, D/Max-2550 PC).

\section{RESULTS AND DISCUSSION}

\section{Effect of ZVI Dosage on the Removal of Reactive Black by ZVI}

The study investigated the effect of different ZVI dosages on the removal of reactive black by ZVI, as shown in Fig. 1(A). When the ZVI dosage was 0.1 g. $\mathrm{L}^{-1}$, the removal rate of the reactive black by ZVI was only $40 \%$ and reactive black cannot be degraded after $30 \mathrm{~min}$. When the ZVI dosage was $0.3 \mathrm{~g} . \mathrm{L}^{-1}$, the removal rate was reached $60 \%$ at 15 min, and the reactive black removal rate reached $80 \%$ at 30 min. When the ZVI dosage was $0.5 \mathrm{~g} . \mathrm{L}^{-1}$, the reactive black removal rate reached $100 \%$ at $15 \mathrm{~min}$. The reason was that the reduction reaction of ZVI occurs on the surface of iron powder particles (Cao et al. 1999). Therefore, the more iron powder was added and the larger the surface area of the iron powder provided by the unit reaction volume, that made the removal rate faster.

\section{Effect of Different pH on the Removal of Reactive Black by ZVI}

The effect of different $\mathrm{pH}$ on the removal of reactive black by ZVI was studied, as shown in Fig. 1(B). ZVI completely removed the reactive black in $15 \mathrm{~min}$ when $\mathrm{pH}=4$. When $\mathrm{pH}=5$, the removal rate of reactive black by ZVI was about $60 \%$ at $15 \mathrm{~min}$ and the removal rate can reach $80 \%$ at 30 min. When $\mathrm{pH}=6$, the removal rate of reactive black by $\mathrm{ZVI}$ was about $27 \%$ at $60 \mathrm{~min}$, the degradation rate was slower and the reaction was incomplete. When $\mathrm{pH}=7$, ZVI hardly removed the reactive black. The reason was that, under alkaline conditions, a passivation film was formed on the surface of the ZVI and preventing further occurrence of the removal reaction. Under acidic conditions, it was beneficial to increase the corrosion rate of ZVI, promoted the reduction reaction and improved the effect of degrading reactive black. This is consistent with the conclusions of Bai \& Wang (2008). The reactive black removal by ZVI was more $\mathrm{pH}$ dependent.

\section{Effect of Reaction Temperature on the Removal of Reactive Black by ZVI}

Table 1: Molecular structure of the reactive black.

\begin{tabular}{|lll}
\hline Name & Dye structure & Maximum absorption wavelength \\
\hline Reactive black & & \\
\hline
\end{tabular}


The experiment investigated the effects of different temperatures on the removal of reactive black by ZVI, as shown in Fig. 1(C). When the temperature was $298 \mathrm{~K}$, the ZVI removed about $80 \%$ of the reactive black at $60 \mathrm{~min}$. When the temperature was $278 \mathrm{~K}$, the degradation rate of reactive black was poor. However, the reactive black was completely degraded by ZVI for about 60 minutes at a temperature of $318 \mathrm{~K}$. This may be due to the increase in temperature, which accelerated the corrosion of ZVI surface and thereby increasing the degradation rate. This is consistent with the conclusions of Mielczarski et al. (2005). The experimental data showed that the increase of temperature was beneficial to the degradation of reactive black by ZVI, indicating that the degradation reaction of reactive black removal by ZVI was endothermic.

In general, the reaction temperature plays a key role in the chemical reaction. In the course of the reaction, the concentration of the remaining solution in the study according to Shu et al. (2007) and Fan et al. (2009) can be
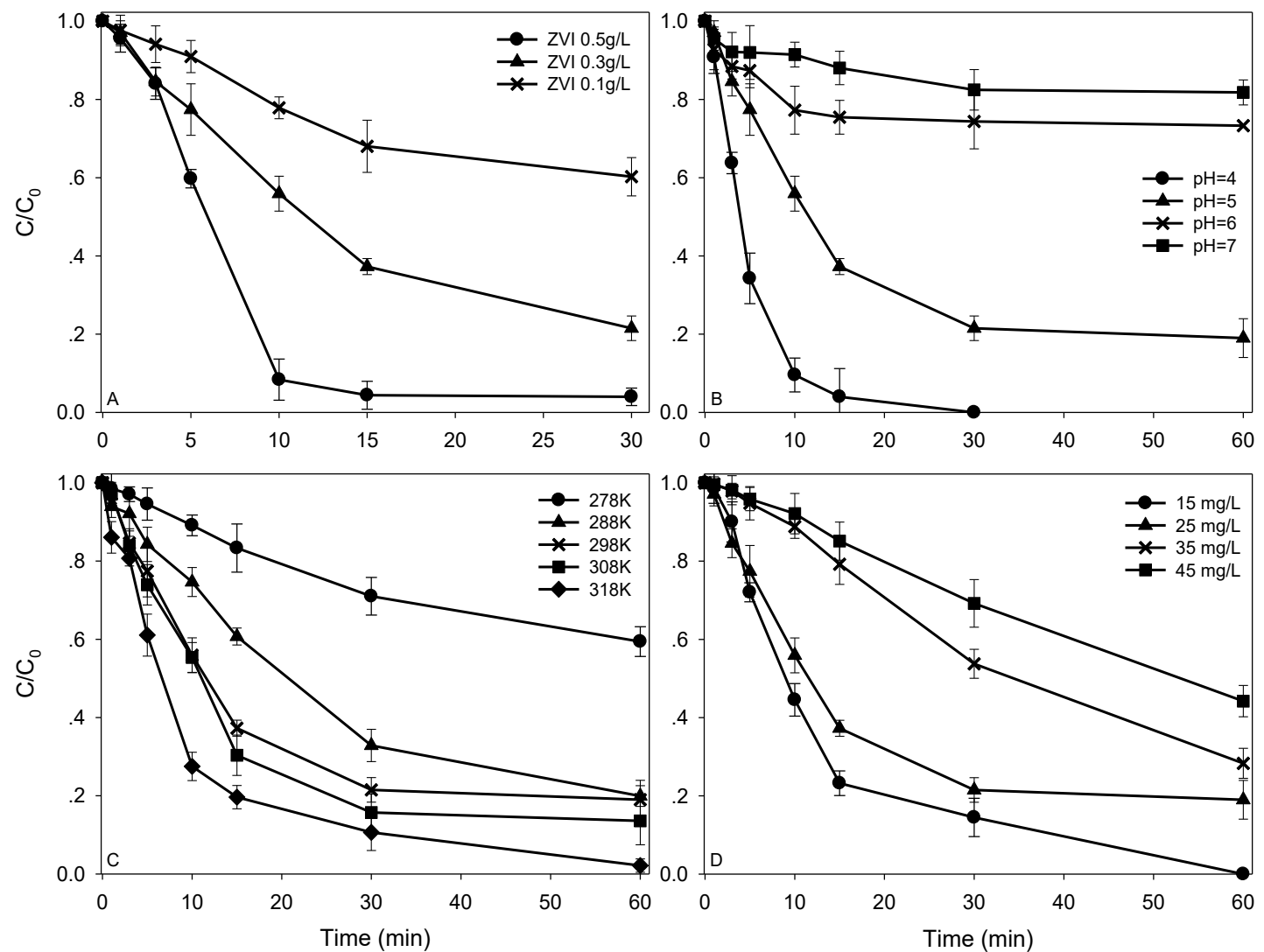

Fig. 1: Effect of different operating conditions on the removal of reactive black by ZVI.

[ A:T=298K, 0.01M HAc-NaAc buffer $\mathrm{pH}=5$, reactive black $25 \mathrm{mg} . \mathrm{L}^{-1} ; \mathrm{B}: \mathrm{T}=298 \mathrm{~K}$, ZVI $0.3 \mathrm{~g} . \mathrm{L}^{-1}$, reactive black $25 \mathrm{mg} . \mathrm{L}^{-1}$,

$0.01 \mathrm{M}$ HAc-NaAc buffer $\mathrm{pH}=4$ and $\mathrm{pH}=5,0.01 \mathrm{M}$ MES buffer $\mathrm{pH}=6,0.01 \mathrm{M}$ TRIS buffer $\mathrm{pH}=7$; C:ZVI 0.3 g. $\mathrm{L}^{-1}, 0.01 \mathrm{M} \mathrm{HAc}-\mathrm{NaAc}$ buffer $\mathrm{pH}=5$, reactive black $25 \mathrm{mg} . \mathrm{L}^{-1}$; D: T=298K, 0.01M HAc-NaAc buffer $\mathrm{pH}=5$, ZVI $0.3 \mathrm{~g} . \mathrm{L}^{-1}$ ] by combination of nano zero-valent iron and a EGSB Reactor.

Environ. Sci. Technol., 39(05): 80-84. 


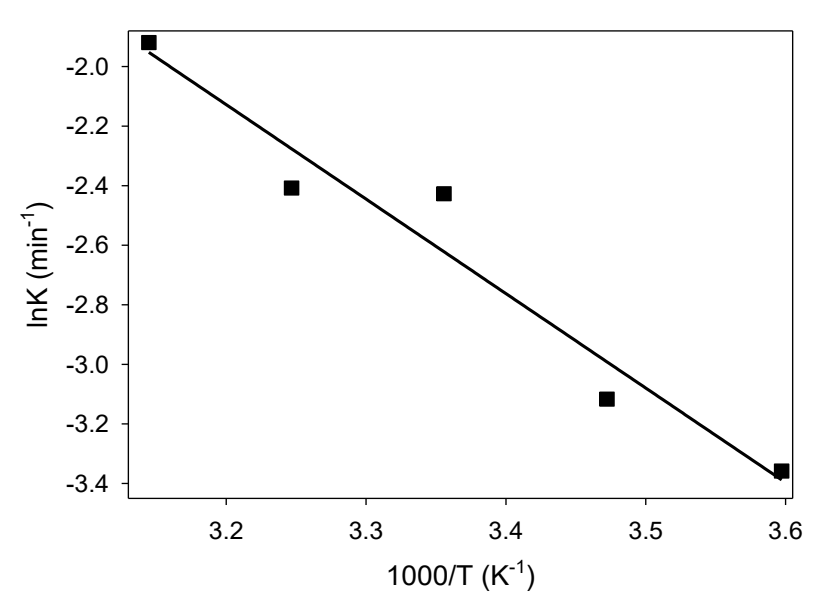

Fig. 2: Arrhenius plot for reactive black removal by ZVI. [0.01M HAc-NaAc buffer $\mathrm{pH}=5$, reactive black $25 \mathrm{mg} . \mathrm{L}^{-1}$, ZVI 0.3 g.L ${ }^{-1}$ ]

was close to the ZVI removal Se(IV) activation energy Ea (32.86 $\mathrm{KJ} \mathrm{mol}^{-1}$ ) (Liang et al. 2015). The activation energy Ea of a general chemical reaction is between 60 and $250 \mathrm{KJ}$ $\mathrm{mol}^{-1}$ (Fan et al. 2009). The value of the activation energy was small indicating that this reaction was easy to occur and the temperature dependence on practical applications was small.

\section{Effect of Reactive Black Concentration on the Removal of Reactive Black by ZVI}

The experiment investigated the effect of different dye concentrations on the removal of reactive black by ZVI, as shown in Fig. 1(D). When the initial concentration of the solution was $15 \mathrm{mg} . \mathrm{L}^{-1}$, the removal rate of reactive black was about $76 \%$ and the ZVI almost completely removed the reactive black at $60 \mathrm{~min}$. As the concentration of reactive black increased, the removal rate of ZVI decreased. This is consistent with Guo et al. (2010). Zhong et al. (2016) had also found that in the case of a certain concentration of pollutants, with the same dosage and as the initial concentration of the solution increases, the removal rate of pollutants in the same reaction time would decrease.

\section{The Effect of Coexisting Ions on the Removal of Reactive Black by ZVI}

A large amount of dissolved inorganic anions and metal cations usually present in the dye wastewater, and they cannot be completely removed even after the pretreatment of adsorption or filtration. Therefore, the effect of coexisting ions on the reaction was investigated. Two cations $\left(\mathrm{Ca}^{2+}, \mathrm{Mg}^{2+}\right)$ and six anions $\left(\mathrm{CO}_{3}{ }^{2-}, \mathrm{SO}_{4}{ }^{2-}, \mathrm{ClO}_{4}{ }^{-}, \mathrm{HCO}_{3}{ }^{-}, \mathrm{PO}_{4}{ }^{3-}, \mathrm{NO}_{3}{ }^{-}\right)$were selected to investigate the effect of coexisting ions on reactive black removal by ZVI. The results were shown in Fig. 3.

From Fig. $3 \mathrm{~A}$, it could be seen that $\mathrm{SO}_{4}{ }^{2-}$ promoted the removal of reactive black by $\mathrm{ZVI}$. $\mathrm{SO}_{4}{ }^{2-}$ promoted the removal of reactive black by ZVI and promoted the effect gradually on the reaction after 15 minutes. At $15 \mathrm{~min}$, the removal rate of reactive black by ZVI with the non-ion group was about $62 \%$, while the removal rate of $\mathrm{SO}_{4}{ }^{2-}$ group was about $77 \%$. As the reaction progressed, the promotion of $\mathrm{SO}_{4}{ }^{2-}$ decreased gradually within 15 to 30 minutes and the promotion of $\mathrm{SO}_{4}{ }^{2-}$ gradually stabilized after 30 minutes. Also, the removal rate of the reactive black by the ZVI with the non-ion group was about $62 \%$, and the removal rate with
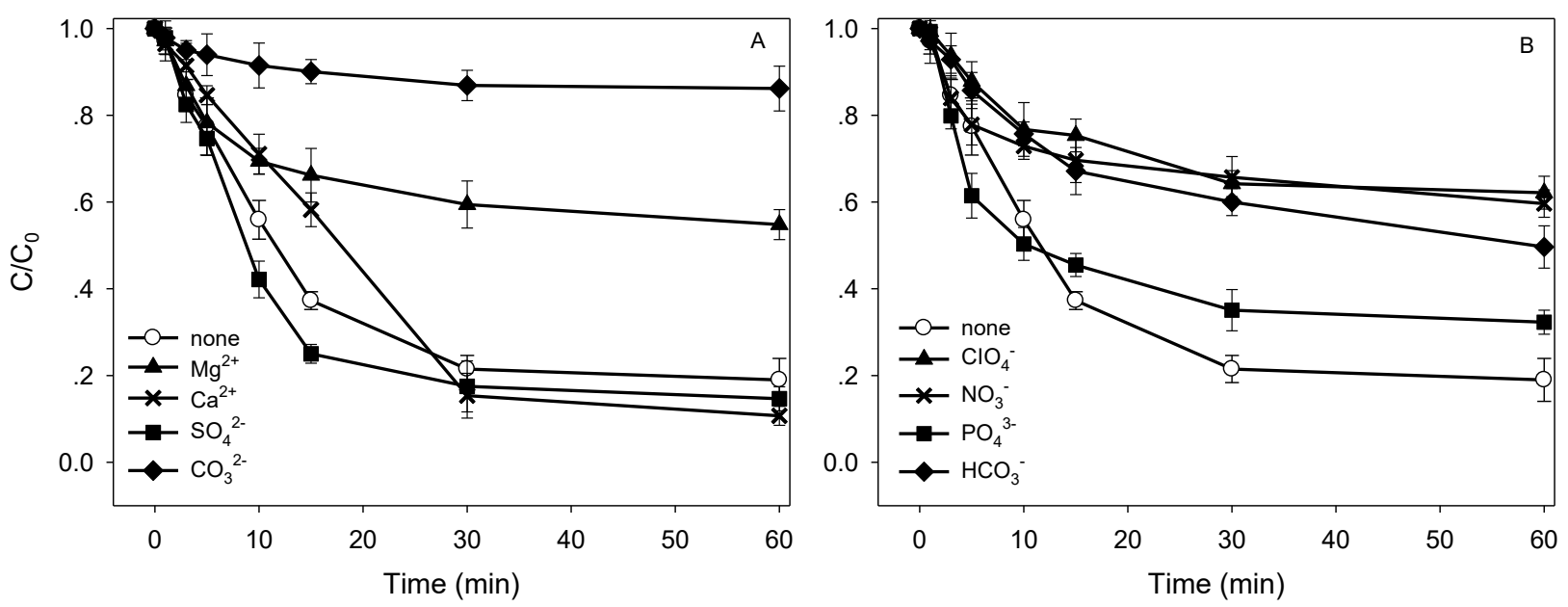

Fig. 3: Effect of coexisting ions on the removal of reactive black by ZVI.

[T=298K, 0.01M HAc-NaAc buffer $\mathrm{pH}=5$, reactive black $25 \mathrm{mg} . \mathrm{L}^{-1}$, ion concentration $10 \mathrm{mmol.L}{ }^{-1}$, ZVI 0.3 g.L $\mathrm{L}^{-1}$ ] 
the $\mathrm{Ca}^{2+}$ group was about $41 \%$ after $15 \mathrm{~min}$. As the reaction progressed, it was observed that the degradation rates with the non-ion group and the $\mathrm{Ca}^{2+}$ group were almost the same at about $27 \mathrm{~min}$. After $27 \mathrm{~min}$, the $\mathrm{Ca}^{2+}$ group gradually increased the promoting effect of ZVI removal of reactive black and the growth rate of the promoting effect decreased gradually after $30 \mathrm{~min}$. At $60 \mathrm{~min}$, the removal rate with $\mathrm{Ca}^{2+}$ group was about $88 \%$, while the removal rate with non-ion group was about $80 \%$. In general, the $\mathrm{Ca}^{2+}$ group had an inhibitory effect on the removal of the reactive black by ZVI and promoted it later.

The degradation rates of $\mathrm{Mg}^{2+}, \mathrm{CO}_{3}{ }^{2-}, \mathrm{ClO}_{4}{ }^{-}, \mathrm{NO}_{3}{ }^{-}, \mathrm{PO}_{4}{ }^{3-}$ and $\mathrm{HCO}_{3}^{-}$were lower than those with the non-ion group, as shown in Fig. $3 \mathrm{~A}$ and $\mathrm{B}$. Among them, $\mathrm{PO}_{4}{ }^{3-}$ group promoted ZVI removal of reactive black in the first of 12 minutes. However, after 12 min $\mathrm{PO}_{4}{ }^{3-}$ gradually hindered the degradation of reactive black by ZVI. At $30 \mathrm{~min}$, the degradation rate of the $\mathrm{PO}_{4}{ }^{3-}$ group gradually stabilized by about $63 \%$ lower than that of the non-ion group by $78 \%$. Besides, $\mathrm{CO}_{3}{ }^{2-}$ had an obvious inhibitory effect on the reaction. The removal rate of ZVI with the non-ion group was about $62 \%$ at $15 \mathrm{~min}$, compared with about $8 \%$ with $\mathrm{CO}_{3}{ }^{2-}$ group. The removal rate of $\mathrm{CO}_{3}{ }^{2-}$ group increased slowly and reached stability after $30 \mathrm{~min}$. Meantime, $\mathrm{Mg}^{2+}$ group also had an inhibitory effect on the reaction. In the first 10 minutes, the removal rate of $\mathrm{Mg}^{2+}$ group increased rapidly and reached $29 \%$ at 10 min. After 10 minutes, the removal rate of $\mathrm{Mg}^{2+}$ group increased slowly and reached $43 \%$ at $60 \mathrm{~min}$, while the removal rate of the non-ion group was about $80 \%$. Furthermore, the $\mathrm{HCO}_{3}^{-}, \mathrm{NO}_{3}^{-}, \mathrm{ClO}_{4}^{-}$groups all hindered the degradation of reactive black by ZVI. It was indicated that these six ions had inhibitory effects on the removal of reactive black by $\mathrm{ZVI}$ to the extent of $\mathrm{CO}_{3}{ }^{2-}>\mathrm{ClO}_{4}{ }^{-}>\mathrm{NO}_{3}{ }^{-}>$ $\mathrm{HCO}_{3}{ }^{-}>\mathrm{Mg}^{2+}>\mathrm{PO}_{4}{ }^{3-}$.

\section{Mechanism Analysis}

UV-Vis scanning analysis: To investigate the process of degrading reactive black with ZVI, the types of intermediate products were qualitatively analysed and the water samples at a different time in the reaction process were studied. UV-Vis scan with a scanning range of $200 \mathrm{~nm} \sim 600 \mathrm{~nm}$. The decolourization of dye was seen from the UV spectrum, and the degradation process of dye was analysed. As shown in Fig. 4, there are four absorption peaks at 230, 310, 390, $510 \mathrm{~nm}$. Among them, $510 \mathrm{~nm}$ in the visible region is the characteristic absorption peak of the azo double bond. The absorption peak of $390 \mathrm{~nm}$ represents the cis structure absorption peak of dye. $230 \mathrm{~nm}, 310 \mathrm{~nm}$ are aromatic functional groups, which represent the characteristic absorption peaks of naphthalene ring structure and benzene ring structure of reactive black molecules, respectively.
With the progress of degradation reaction, the characteristic peak at $510 \mathrm{~nm}$ in visible light region weakens rapidly. When the reaction reached $30 \mathrm{~min}$, it can be seen that the characteristic absorption peak of azo double bond at $510 \mathrm{~nm}$ had disappeared, indicating that the azo double bond in dye molecule had been destroyed at this time (Zhang et al. 2015). It can be calculated from Fig. 4 that the removal rate of reactive black by ZVI was about $90 \%$ when the reaction was $30 \mathrm{~min}$, which also showed that the azo bond in dye molecule was easy to be destroyed (Zhang et al. 2013). At the same time, it can be observed during the experiment that the original blue and black colour of the dye had disappeared, and the solution presented a faint fuchsia colour. The absorption peak at $390 \mathrm{~nm}$ at $30 \mathrm{~min}$ also basically disappeared, which indicated that the conjugated system of dye and the structure of dye are destroyed at the same time. In addition, with the progress of the reaction, it can be observed from the diagram that the absorption peak of the naphthalene ring structure of $230 \mathrm{~nm}$ was gradually weakened. However, the absorption peak of benzene ring structure at $310 \mathrm{~nm}$ increased gradually, which indicated that the new benzene ring was produced by the degradation and ring-opening of naphthalene ring (Yang et al. 2012). After the reaction, there was still an absorption peak in the structure of the benzene ring at $310 \mathrm{~nm}$, which indicated that the benzene ring had not been completely degraded.

Characterization of solid products: To find out the variation of corrosion products after the reaction, scanning electron microscope (SEM) and x-ray diffraction (XRD) were used to analyze the samples after ZVI removal of reactive black for $120 \mathrm{~min}$. As can be seen from Fig. 5, it can be seen that the ZVI particles are smooth and irregular in the 0 min of reaction, and the distribution is uniform. After the reaction

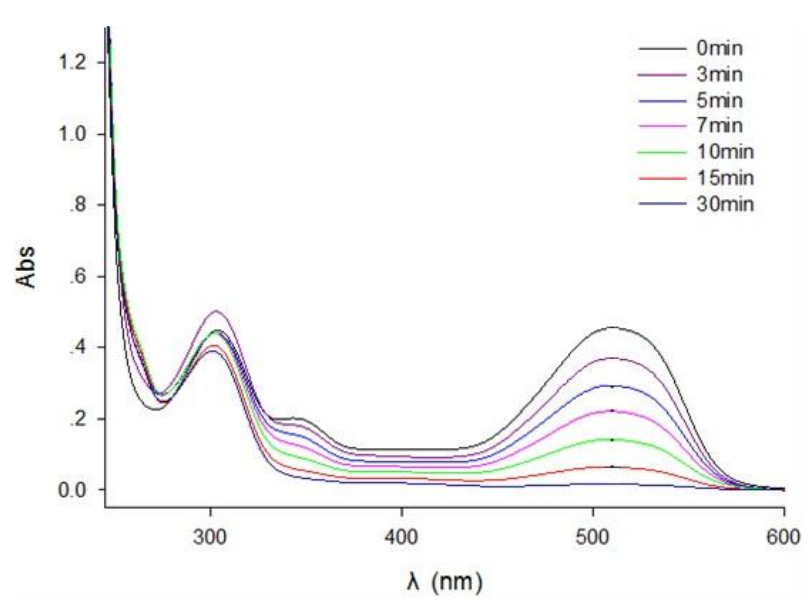

Fig. 4: UV-Vis scanning spectra of reactive black removed by ZVI at different reaction time.

$\left[\mathrm{T}=298 \mathrm{~K}, 0.01 \mathrm{M}\right.$ HAc-NaAc buffer $\mathrm{pH}=5$, reactive black $25 \mathrm{mg} . \mathrm{L}^{-1}$, ZVI 0.3 g.L - $^{-1}$ 
of $120 \mathrm{~min}$, the shape of ZVI particles did not change much. However, the surface of the particles became rough, which was caused by the corrosion of the particle surface and the formation of iron oxide or iron hydroxide during the reaction process (Zhao et al. 2018).

To further understand the product change before and after the removal of reactive black by ZVI, the material after the reaction was characterized by $\mathrm{x}$-ray diffraction, as shown in Fig. 6. Among them, $2 \theta$ was 44.7, 65.04, 82.34 was the characteristic diffraction peak of ZVI (PDF 06-0696) and the characteristic diffraction peak may be that the incomplete reaction residual of ZVI was more. The weak characteristic diffraction peak of $\mathrm{Fe}_{2} \mathrm{O}_{3}$ (PDF 21-920) was observed when
$2 \theta$ was 38.44 , which indicated that part of the material was oxidized after the reaction. It was consistent with the conclusion of SEM analysis.

\section{CONCLUSIONS}

Removal of reactive black by ZVI had a great degradation effect. The addition of ZVI, $\mathrm{pH}$ value of the solution, initial concentration of reactive black, temperature and common coexisting ions in the water had different effects on the removal of reactive black by ZVI. Among them, the lower the $\mathrm{pH}$, the more acidic conditions helped to increase the corrosion rate of ZVI. It promoted a reduction reaction and can improve the effect of degradation reactive black. The

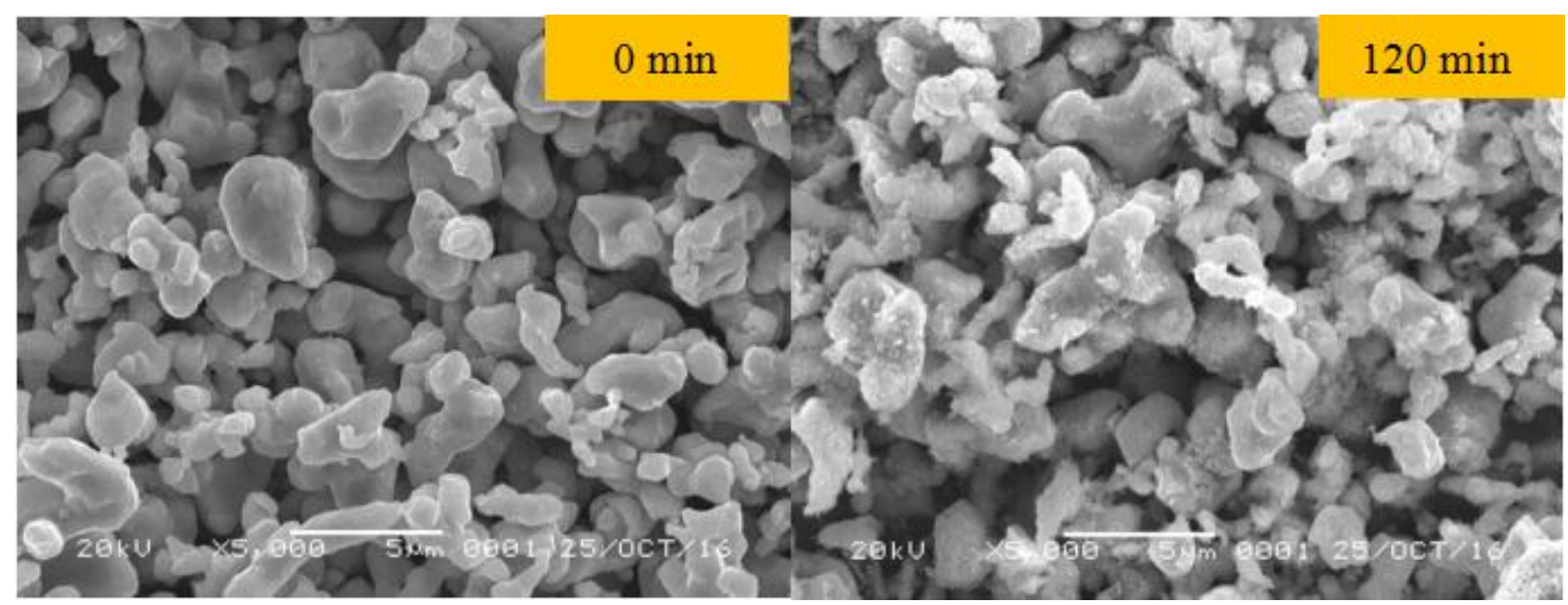

Fig. 5: SEM images of reactive black removal by ZVI at different time. $\left[\mathrm{T}=298 \mathrm{~K}, 0.01 \mathrm{M}\right.$ HAc-NaAc buffer $\mathrm{pH}=5$, reactive black $\left.25 \mathrm{mg} . \mathrm{L}^{-1}, \mathrm{ZVI} 0.3 \mathrm{~g} . \mathrm{L}^{-1}\right]$

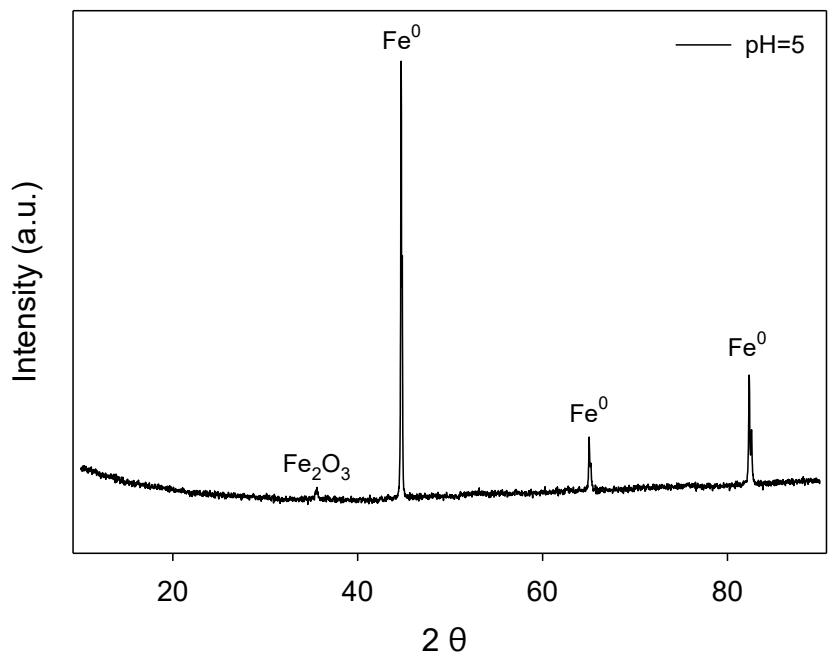

Fig. 6: XRD pattern of activity black removed by ZVI at $\mathrm{pH}=5$.

$\left[\mathrm{T}=298 \mathrm{~K}, 0.01 \mathrm{M}\right.$ HAc-NaAc buffer $\mathrm{pH}=5$, reactive black $25 \mathrm{mg} . \mathrm{L}^{-1}$, ZVI $\left.0.3 \mathrm{~g} . \mathrm{L}^{-1}\right]$ 
existence of $\mathrm{SO}_{4}{ }^{2-}$ can promote the removal of reactive black by ZVI and the existence of $\mathrm{Ca}^{2+}$ can inhibit the removal of reactive black by $\mathrm{ZVI}$ at the early stage and promote at the later stage. However, the existence of $\mathrm{Mg}^{2+}, \mathrm{CO}_{3}{ }^{2-}, \mathrm{ClO}_{4}{ }^{-}$, $\mathrm{NO}_{3}{ }^{-}, \mathrm{PO}_{4}{ }^{3-}$ and $\mathrm{HCO}_{3}{ }^{-}$can inhibit the removal of reactive black. The degradation process was analysed by UV-vis, $\mathrm{SEM}, \mathrm{XRD}$. The main reaction product was $\mathrm{Fe}_{2} \mathrm{O}_{3}$.

\section{ACKNOWLEDGEMENTS}

This research was financially supported by the National Natural Science Foundation of China (Grant No. 41807468), Zhejiang Provincial Natural Science Foundation of China (Grant No. LY18E080018), and State Key Laboratory of Pollution Control and Resource Reuse Foundation (NO. PCRRF18021).

\section{REFERENCES}

Bai, S.Y. and Wang, M.Y. 2008. Review on contaminated water remediation by nanoscale zero-valent iron (in Chinese). Water Purif. Technol., 27(1):35-40.

Bao, Q.Q., Li, J.X. and Guan, X.H. 2017. Improving the reactivity of zerovalent iron toward various azo dyes by pre-magnetization. Environ. Chem., 36(07):1467-1473.

Cao, J.S., Wei, L.P., Huang, Q.G., Wang, L.S. and Han, S.K. 1999. Reducing degradation of azo dye by zero-valent iron in aqueous solution. Chemosphere, 38(3): 565-571.

Epolito, W.J., Yang, H., Bottomley, L.A. and Pavlostathis, S.G. 2008. Kinetics of zero-valent iron reductive transformation of the anthraquinone dye Reactive Blue 4. J. Hazard. Mater., 160(2-3): 594-600.

Fan, J., Guo, Y.H., Wang, J.J. and Fan, M.H. 2009. Rapid decolorization of azo dye methyl orange in aqueous solution by nanoscale zerovalent iron particles. J. Hazard. Mater., 166(2-3): 904-910.

Feng, P., Zhou, Q.L., Guan, X.H. and Zhou, G.M. 2014. Preliminary study on the effect of zero valent iron enhanced by weak magnetic field on the azo dyes decoloration in the water. Sichuan Environ., 33(4): 1-6.

Fu, F.L. 2010. Newest research progress in the application of zero-valent iron to the treatment of wastewater. Ind. Water Treat., 30(6): 1-4.

Guan, X.H., Sun, Y.K., Qin, H.J., Li, J.X., Irene, M.C.L., He, D. and Dong, H.R. 2015. The limitations of applying zero-valent iron technology in contaminants sequestration and the corresponding countermeasures: The development in zero-valent iron technology in the last two decades (1994-2014). Water Res., 75: 224-248.
Guo, Y., Xiao, L.P., Deng, Z.Y. and Tang, W.Q. 2010. Laboratory study on the decolorization of reactive brilliant blue X-BR treated by an integrated $\mathrm{Fe}^{0}$-anaerobic biological system. China Environ. Sci., 30(4): 510-515.

Khan, A., Prabhu, S.M., Park, J., Lee, W. and Lee, G. 2016. Azo dye decolorization by ZVI under circum-neutral $\mathrm{pH}$ conditions and the characterization of ZVI corrosion products. J. Ind. Eng. Chem., 47: 86-93.

Liang, L.P., Jiang, X., Yang, W.J., Huang, Y.Y., Guan, X.H. and Li, L. 2015. Kinetics of selenite reduction by zero-valent iron. Desalin. Water Treat., 53(9): 2540-2548.

Ludwig, R.D., Smyth, D.J.A., Blowes, D.W., Spink, L.E. and Weisener, C.J. 2009. Treatment of arsenic, heavy metals, and acidity using a mixed ZVI-compost PRB. Environ. Sci. Technol., 43(6): 1970-1976.

Mielczarski, J.A., Atenas, G.M. and Mielczarski, E. 2005. Role of iron surface oxidation layers in decomposition of azo-dye water pollutants in weak acidic solutions. Appl. Catal., B., 56(4): 289-303.

Qiu, L.J. 2010. Study on adsorption and degradation of Reactive Black KN-B by three kinds of sludge. Chin. J. Environ. Eng., 4(1): 96-100.

Rodríguez-Maroto, J.M., García-Herruzo, F., García-Rubio, A., GómezLahoz, C. and Vereda-Alonso, C. 2008. Kinetics of the chemical reduction of nitrate by zero-valent iron. Chemosphere, 74(6): 804-809.

Shu, H.Y., Chang, M.C., Yu, H.H. and Chen, W.H. 2007. Reduction of an azo dye Acid Black 24 solution using synthesized nanoscale zerovalent iron particles. J. Colloid Interface Sci., 314(1): 89-97.

Wu, Q.Y., Xie, M.Y., Yang, Y., Zhu, R., Han, X.R. and Zou, H. 2017. Study of hydrogen peroxide accumulation for degradation of Reactive Black 5 in the zero-valent aluminum/acid/oxygen system. Environ. Sci. Technol., 40(06): 49-53.

Yang, B., Xie, H. and Zhou, P. 2012. Indirect anodic oxidation applied for the treatment of simulated wastewater containing reactive dyes. Chin. J. Environ. Eng., 5(05): 1091-1095.

Zhang, F.F., Liang, X.M., Zhang, Q., Chen, J.P., Ayfer, Y. and Antonius, K. 2004. Investigation of hydrolysis products of Reactive Black 5 by high performance liquid chromatography/mass spectrometry. Chin. J. Anal. Chem., 32(8): 1019-1022.

Zhang, N., Zou, H., Wu, Q.Y. and Zhu, R. 2015. Enhanced the degradation of Reactive Black 5 by zero valent-aluminum / acid system. Environ. Chem., 34(07): 1343-1349.

Zhang, Y.P., Li, Y.B., Li, F., Li, J. and Li, J. 2013. Degradation efficacy and mechanism of reactive black KBR with ferrate solution. Ind. Water Treat., 33(1): 58-61.

Zhao, Y., Zhu, F. and Ren, W.T. 2018. Kinetics of nitrate removal in groundwater using green synthesized nanoscale zero valent iron-nickel. Environ. Eng., 36(7): 71-76.

Zhong, X.H., Yu, Y., Liu, S.Y., Zhao, J.J., Liu, J., Xia, D.F. and Pan, F. 2016. Study on advanced treatment of printing and dyeing wastewater by combination of nano zero-valent iron and a EGSB Reactor. Environ. Sci. Technol., 39(05): 80-84. 